\title{
Mistä Jääpeili on tehty
}

\section{Veijo Pulkkinen: Runoilija latomossa. Geneettinen tutkimus Aaro Hellaakosken Jääpeilistä. Helsinki: Suomalaisen Kirjallisuuden Seura 2017, 314 S.}

Suomalaisen runouden tutkijoiden tulisi lukea Veijo Pulkkisen uusi tutkimus. Aaro Hellaakosken Jääpeili-klassikon (1928) syntyhistoriaa tarkasteleva Runoilija latomossa on näkemyksellisesti toteutettu runoudentutkimuksen alaa sytyttävä teos, joka uskoakseni palvelee tutkijoita teoria- ja aineistokohtaisista kiinnostuksenkohteista riippumatta.

Pulkkisen teos edustaa geneettistä kritiikkiä eli kirjallisuudentutkimusta, jossa tarkastellaan teosten syntyprosesseja erilaisten käsikirjoitusvaiheeseen liittyvien aineistojen avulla. Suomalaiseen tutkimukseen jo vakiintuneiden tekstuaalitieteiden (arkistotutkimuksen, tekstikritiikin, geneettisen kritiikin) kentässä Pulkkinen tarkentaa tutkimuksensa edustavan geneettistä bibliografiaa. Se keskittyy hahmottamaan tutkimuskohteen visuaalista toteutusta aktiivisina kokeiluina ja valintoina, joihin osallistuu runoilijan lisäksi kirjan latoja. Toteutukseen vaikuttavat kirjailijan omat ja ajassa vallinneet poeettiset, esteettiset ja ideologiset näkemykset sekä kirjanvalmistukseen liittyvät materiaaliset ehdot.

Tutkimus alkaa johdannolla, joka keskittyy avaamaan geneettisen kritiikin sekä erityisesti geneettisen bibliografian teoreettista pohjaa. Geneettisen kritiikin menetelmien ja käsitteistön esittelyn rinnalla Pulkkinen tarkastelee runoudentutkimusta puhuttanutta materiaalisuuden kysymystä sekä selvittää metodologiansa semioottista perustaa. Tutkimuksen ensimmäisessä varsinaisessa luvussa Jääpeiliä käsitellään 1920-luvun modernismikeskustelun kontekstissa. Tämä konteksti on ymmärretty ilahduttavan laajasti: kyse on paitsi suomalaisen runouden sukupolvikiistoista (jotka nekin avartuvat henkilötasolta modernistisen runouden teemojen ja ihanteiden tarkkaan, kriittiseen analyysin) myös avantgardea koskevista kansainvälisistä taidekeskusteluista. Runouden rinnalla Pulkkinen pohtii Hellaakosken estetiikkaa ja poetiikkaa kuvataiteellisissa kubismin, ekspressionismin, klassisismin ja futurismin yhteyksissä, mikä on tutkimuskysymyksen kannalta toki tarpeellistakin.

Tutkimuksen toinen luku paneutuu Jääpeilin runojen syntyhistoriaan. Muun muassa Hellaakosken vuonna 1964 julkaisemaa Runon historiaa -teosta apunaan käyttäen Pulkkinen ruotii Hellaakosken käsityksiä ja kokemuksia runouden kirjoittamisesta, mutta tutkija kuvailee ja luokittelee myös runoilijantyön materiaalista puolta arkistosta löytyneiden käsikirjoitusten ja luonnosten perusteella. Kun analyysin tueksi valikoituu vielä Hellaakosken muu kaunokirjallinen 
ja kaunokirjallisuutta koskeva kirjallinen tuotanto, Hellaakosken henkilökohtaisen kirjaston valikoima, suomalainen Hellaakoski-tutkimus sekä vaikuttava määrä poimintoja länsimaisen kirjallisuuden historiasta, Pulkkinen kykenee tekemään vakuuttavia tulkintoja Jääpeilin syntyprosessista.

Tutkimuksen kolmas, pisin luku keskittyy runoteoksen typografisen ulkoasun synnyn tutkimiseen. Typografian ja kirjataiteen kysymysten kannalta osuvasti Hellaakosken käsityksiä kuvan ja sanan suhteesta käsitellään luvun alussa, ja samalla syntyy tärkeitä kytkentöjä tutkimuksen alkua hallinneeseen modernismikeskusteluun. Analyysi tarkentuu luvun loppua kohti yhä pienempiin yksityiskohtiin Jä̈peilin ulkoasussa, jonka merkkikohtaisia ratkaisuja luetaan koko ajan valinnan ja etsinnän prosessina, erilaisia käsikirjoitusliuskoja ja niiden latojalle osoitettuja merkintöjä tarkastellen. Häkellyttävällä tarkkuudella Pulkkinen analysoi kokoelman runojen kirjasin- ja välimerkkivalintoja sekä näiden yhteyksiä ja seurauksia runojen sanoman kiteytymiselle. Samalla esiin nousee kiinnostavia kulttuurihistoriallisia seikkoja, kuten 1800- ja 1900-lukujen vaihteessa käyty keskustelu suomalaisiin painotuotteisiin parhaiten sopivasta kirjasintyypistä. Tutkimus huipentuu Hellaakosken runojen "Sade", "Kesien kesä" ja "Dolce far niente" yksityiskohtaiseen tarkasteluun, jossa geneettinen menetelmä, typografinen analyysi ja temaattinen tulkinta kytketään yhteen.

Pulkkisen tutkimus on äärimmäisen huolellisesti tehty. Lukija saa nähdäkseen kattavat, mielekkäästi valikoidut kuvat sekä Hellaakosken arkistosta löytyvistä Jä̈peilin käsikirjoituksista, luonnoksista ja korjausvedoksista että muutamista muiden kirjailijoiden avainteksteistä ja kirjankansista. Lukijan apuna toimivat myös asiasana- ja henkilöhakemistot sekä tutkijan järjestelmällisyys aineistonsa merkinnöissä ja analyyttisessa hallinnassa.

Erityisen arvokkaan Pulkkisen teoksesta runoudentutkijoille tekee sen tarjoama analyysivälineiden ja menetelmien kokoelma. Tutkimus opastaa lukijansa geneettisen tutkimuksen ja sen moninaisen käsitteistön pariin, tarkastelemaan runoilijantyötä ja kirjoittamisen prosessuaalisuutta. Runouden visuaalisuuden ja typografisten ratkaisujen analyysiin Pulkkinen kehittää useita näkökulmia ja käsitteellisiä välineitä, joista mainittakoon esimerkkeinä säkeiden sijoitteluun liittyvät horisontaalinen ja vertikaalinen asemointi. Ihailtavaa on lukemisen ja katsomisen - periksi antamaton tarkkuus. Runoilija latomossa on inspiroiva esimerkki siitä, mitä kaikkea kaunokirjallisessa teoksessa voidaan asettaa systemaattisen analyysin kohteeksi.

\section{Karoliina Lummaa}

